\title{
Major- and trace-element compositional variation of phlogopite from kimberlites and carbonatites as a petrogenetic indicator
}

\author{
Ekaterina Reguir ${ }^{1}$, Anton Chakhmouradian ${ }^{1}$, Norman Halden ${ }^{1}$, Vladimir Malkovets ${ }^{2}$ and \\ Panseok Yang ${ }^{1}$ \\ ${ }^{1}$ Dept. of Geological Sciences, University of Manitoba, Winnipeg, Canada \\ ${ }^{2}$ Institute of Mineralogy and Petrography, Novosibirsk, Russia
}

\section{Introduction}

There is a number of volatile-rich mantle-derived rocks (including carbonatites, olivine melilitites, and ultramafic lamprophyres) that may resemble kimberlites in terms of their textural, chemical and mineralogical characteristics (e.g., Mitchell, 1995; Chakhmouradian et al., 2009). Ferromagnesian trioctahedral micas are a common macrocryst/phenocryst phase in both kimberlites and carbonatites. Their composition is sensitive to changes in temperature, pressure and chemistry of crystallization environment, which, in addition to their long crystallization span, makes them an important petrogenetic indicator (e.g., Bagdasarov et al., 1985; Tischendorf et al., 2001). The major-element chemistry of phlogopite from kimberlites and carbonatites has been addressed in many studies (e.g., Lee et al., 2003; Grègoire et al., 2003). However, there is virtually no published data on the trace-element composition of phlogopite from kimberlites and carbonatites. This is in contrast to the voluminous trace-element data available in the literature for phlogopite from mantle xenoliths.

In this work, we explored the possibility of using the chemistry of ferromagnesian micas from kimberlites and carbonatites (with an emphasis on trace elements) to discriminate between these rocks. We determined the extent of compositional variation of micas from 14 selected kimberlite and carbonatite localities worldwide representing several different kimberlite fields and alkaline-carbonatite provinces. Only large crystals (macrocrysts and phenocrysts) were selected for this purpose. We used electron microprobe analysis for major-element analyses, and laser-ablation inductively-coupled-plasma mass-spectrometry (LAICP-MS) for trace-element determinations.

\section{Petrography of the samples}

All carbonatites examined in the present work are intrusive and characterized by diversified mineralogy, highly variable proportions of major and minor phases, and an inequigranular texture. We restricted this review to calcite ( \pm dolomite) carbonatites because calcite and dolomite are the most abundant carbonate minerals in kimberlites. The inequigranular texture of the examined carbonatites is due to large crystals of phlogopite and other ferromagnesian silicates, apatite and magnetite set in a carbonate mesostasis. In the majority of samples, the latter is composed predominantly of calcite with minor dolomite, developed interstitially and along fractures in the earlier-formed phases. All carbonatite samples contain variable proportions of phlogopite ranging from 10 to 40 vol.\%. The mineral forms strongly pleochroic subhedral to euhedral grains ranging in size from less than $0.4 \mathrm{~mm}$ to several $\mathrm{cm}$. Large phlogopite crystals frequently contain inclusions of earlier-crystallized phases, most commonly apatite and magnetite.

The studied kimberlites are hypabyssal and diatremefacies rocks. In the majority of the samples, the macrocryst suite is represented by olivine, phlogopite, spinel and ilmenite. The fine-grained groundmass is composed predominantly of serpentine and calcite with subordinate quantities of spinel-group minerals, perovskite, apatite, fragments of macrocrysts, and disaggregated wallrock material. Phlogopite is present in variable proportions, and makes up from 3 to 10 vol. $\%$ of the rock. In addition to macrocrysts, phlogopite occurs in peridotite xenoliths, pelletal lapilli, and in the groundmass. Phlogopite is commonly replaced by serpentine; however, the degree of replacement varies considerably among the samples.

\section{Major-element composition}

Our data show that carbonatitic micas cover a larger compositional range in terms of their $\mathrm{Mg}$ and $\mathrm{Al}$ contents than macrocrysts from kimberlites (10-29 wt. $\% \mathrm{MgO}$ and 2-22 wt. $\% \mathrm{Al}_{2} \mathrm{O}_{3}$ in carbonatites vs. 22 27 wt. $\% \mathrm{MgO}$ and 11-20 wt. $\% \mathrm{Al}_{2} \mathrm{O}_{3}$ in kimberlites). Notably, however, the samples from the two rock types exhibit significant overlap in their $\mathrm{Mg}$ and $\mathrm{Al}$ values. Kimberlitic phlogopite spans a much smaller range in $\mathrm{Fe} /(\mathrm{Fe}+\mathrm{Mg})$ values $(0.02-0.16)$ than micas from carbonatites (0.04-0.57). Some mica compositions from carbonatites straddle across the phlogopite-annite boundary. In kimberlites, Fe-rich micas ( $>12$ wt.\% 
$\mathrm{FeO}_{\mathrm{T}}$ ) correspond to Al-deficient members (including tetra-ferriphlogopite) and are confined to the groundmass (Mitchell, 1995). However, in common with other major elements, overlap between the Mgrich compositions from the two rock types is too extensive to allow their reliable discrimination. The $\mathrm{Ti}$ contents measured in the present work are comparable in micas from both rock types, but reach somewhat higher levels in the carbonatites (up to 5 wt. \% $\mathrm{TiO}_{2}$ ) relative to the kimberlites $\left(\leq 4\right.$ wt. $\left.\% \mathrm{TiO}_{2}\right)$. This observation is in general agreement with the published data; i.e. the maximum $\mathrm{Ti}$ content of phlogopite macrocrysts and early groundmass crystals from kimberlites is significantly smaller than that reported for carbonatites $\left(8.1\right.$ and $13.8 \mathrm{TiO}_{2}$, respectively; e.g., Brod et al., 2001; Lee et al., 2003). According to our data, carbonatitic micas are distinguished by their commonly higher $\mathrm{Na}$ levels (up to 1.7 wt.\% $\mathrm{Na}_{2} \mathrm{O}$ ) relative to kimberlitic phlogopite, where the $\mathrm{Na}_{2} \mathrm{O}$ content typically does not exceed $0.3 \mathrm{wt} . \%$ and rarely reaches 0.5 wt. $\%$. This is in accord with the published data: up to 2.1 wt. $\% \mathrm{Na}_{2} \mathrm{O}$ has been reported for phlogopite from the Sokli (Finland) carbonatites (Lee et al., 2003), whereas even the most evolved kimberlitic micas never contain more than 0.7 wt.\% $\mathrm{Na}_{2} \mathrm{O}$ (e.g., Mitchell, 1995; Birkett et al., 2004).

\section{Trace-element composition}

Our data show that micas from the two rock types differ significantly in terms of their $\mathrm{Cr}, \mathrm{Mn}, \mathrm{Ni}$ and $\mathrm{Nb}$ abundances. Phlogopite from the kimberlite samples can be readily distinguished from its carbonatitic counterpart by higher levels of $\mathrm{Cr}$ and $\mathrm{Ni}$ (up to 12030 ppm $\mathrm{Cr}$ and 2060 ppm Ni in the kimberlites versus $\leq$ $315 \mathrm{ppm} \mathrm{Cr}$ and $\leq 470 \mathrm{ppm} \mathrm{Ni}$ in the carbonatites; Fig. 1). In addition, phlogopite from the kimberlites is consistently low in $\mathrm{Mn}(\leq 290 \mathrm{ppm}), \mathrm{Nb}(\leq 33 \mathrm{ppm}), \mathrm{Sr}$ ( $\leq 80 \mathrm{ppm}), \mathrm{Sc}(\leq 8 \mathrm{ppm}), \mathrm{Zr}(\leq 14)$ and, to some extent, $\mathrm{Cs}(\leq 7 \mathrm{ppm})$ and $\mathrm{Ta}(\leq 3 \mathrm{ppm})$ with respect to carbonatitic micas (up to $17200 \mathrm{ppm} \mathrm{Mn,} 1080 \mathrm{ppm}$ $\mathrm{Nb}, 830$ ppm Sr, 80 ppm Sc, 105 ppm Zr, 27 ppm Cs and $19 \mathrm{ppm} \mathrm{Ta).} \mathrm{There} \mathrm{is} \mathrm{very} \mathrm{little} \mathrm{overlap} \mathrm{between}$ the mica compositional fields for kimberlites and carbonatites in terms of $\mathrm{Cr}, \mathrm{Nb}, \mathrm{Mn}, \mathrm{Sr}$ and $\mathrm{Zr}$ contents (Fig. 1). There is substantial overlap in Co values; however, none of the kimberlitic macrocrysts contain less than $40 \mathrm{ppm} \mathrm{Co}$, whereas $90 \%$ of all mica analyses from the carbonatites cluster between 0 and $34 \mathrm{ppm}$ Co. The majority of macrocrystic phlogopite from kimberlites contains less than 3500 ppm Ba, whereas the $\mathrm{Ba}$ content of carbonatitic samples ranges from nil to $2.4 \times 10^{4} \mathrm{ppm}$. Variations in $\mathrm{Rb}$ and $\mathrm{V}$ concentrations in phlogopite are extensive, but comparable in both rock types (180-1050 ppm $\mathrm{Rb}$ and $17-335 \mathrm{ppm} \mathrm{V}$ in kimberlites; 160-1250 ppm Rb and 4-365 ppm V in carbonatites). Phlogopites from all studied samples contain negligible amounts of $\mathrm{Y}(<5 \mathrm{ppm})$, Hf $(<1$ ppm) and rare-earth elements dominated by La and Ce (typically, < $3 \mathrm{ppm}$; in a few cases, up to $10 \mathrm{ppm}$ $\mathrm{La}+\mathrm{Ce})$.
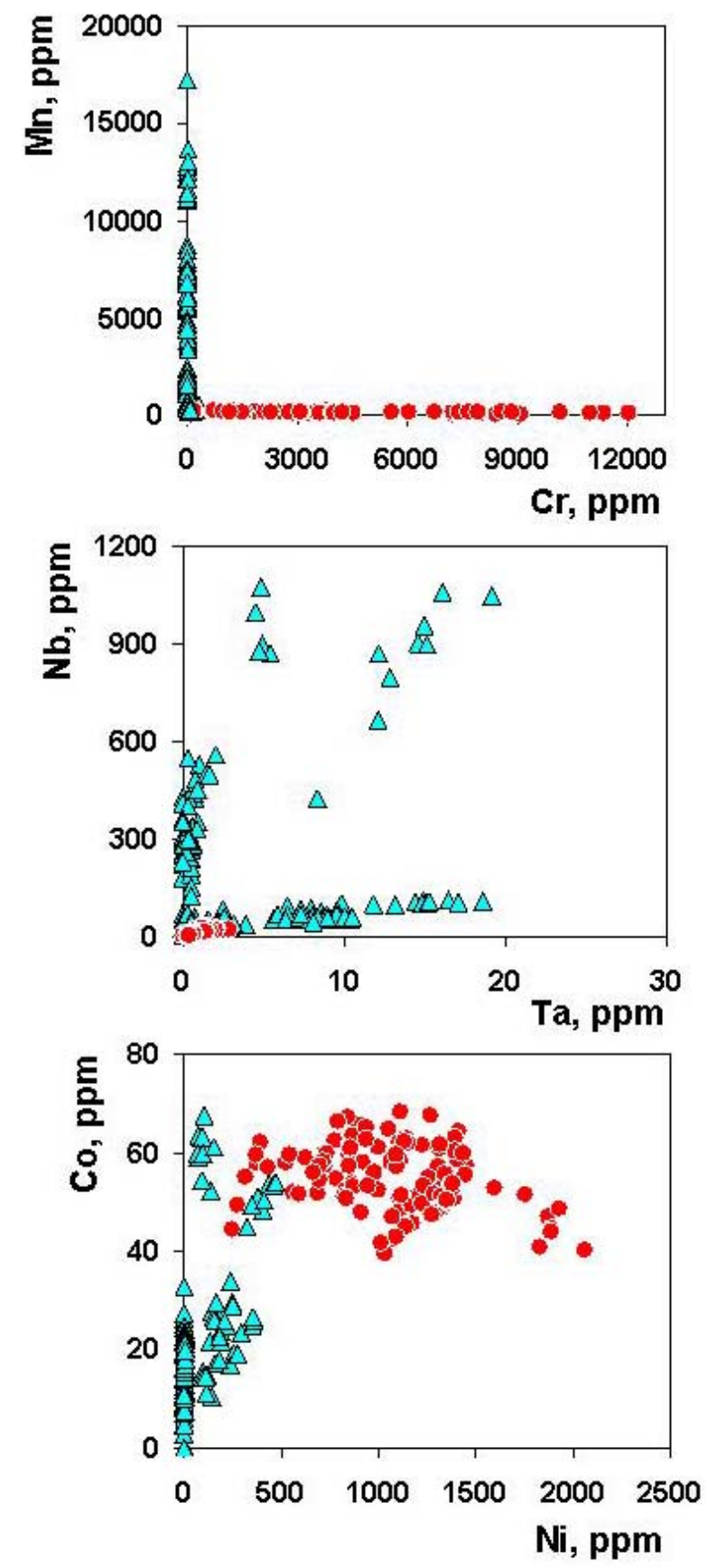

Fig. 1. Variations in minor and trace elements in mica from kimberlites (red circles; total of 121 analyses) and carbonatites (blue triangles; total of 196 analyses) determined by LA-ICP-MS.

\section{Discussion and conclusions}

The mechanisms of atomic substitutions and elementpartitioning behavior in trioctahedral micas have been studied extensively and explained by crystal-chemical, paragenetic and/or physicochemical constraints, in particular $f\left(\mathrm{O}_{2}\right), \quad P\left(\mathrm{H}_{2} \mathrm{O}\right), \quad P\left(\mathrm{CO}_{2}\right)$, pressure and temperature of the crystallization environment, and magma composition (e.g., Lee et al., 2003). Majorelement variations in micas from carbonatites, kimberlites and related alkaline rocks have been discussed previously in a number of studies (e.g., 
Gaspar and Wyllie, 1987; Brod et al., 2001). Our data are in general agreement with the findings of Brod et al. (2001) that there is extensive overlap between the compositional fields of mica from carbonatites and other alkaline rocks. This is especially true in terms of the $\mathrm{Mg}, \mathrm{Al}$ and $\mathrm{Ti}$ contents of the samples studied in the present work. As recognized in Lee et al. (2003) and a number of other studies, Fe-rich biotitic micas observed in some carbonatite samples represent evolved compositions that form owing to progressive depletion of the magma in $\mathrm{Mg}$ (early crystallization of forsterite, magnetite and Mg-rich phlogopite) or preferential partitioning of $\mathrm{Mg}$ in dolomite at the late stages of crystallization. The generally higher levels of $\mathrm{Na}$ in carbonatitic micas can be explained by the higher $\mathrm{Na}$ abundances in carbonatitic magmas relative to kimberlitic magmas. The average carbonatite contains approximately twice the amount of $\mathrm{Na}_{2} \mathrm{O}$ relative to the average composition of hypabyssal kimberlite (Chakhmouradian, unpubl. data). Our data suggest that the differences in $\mathrm{Na}$ content between carbonatitic and kimberlitic mica can be potentially used to discriminate between the two rock types, especially when combined with trace-element data.

Trace-element partitioning between phlogopite and a coexisting melt has been discussed in a number of studies (e.g., Foley, 1996; Schmidt, 1999). The appreciable variability in partition coefficients determined in these studies is probably due to the extreme flexibility of phlogopite structure (Foley et al., 1996). According to the published data, $\mathrm{Cr}, \mathrm{Rb}$ and $\mathrm{Ba}$ are consistently compatible with respect to phlogopite, whereas $\mathrm{Sr}, \mathrm{Zr}$ and $\mathrm{Nb}$ are strongly incompatible across a range of silica-undersaturated melt compositions. Partition coefficients of other trace elements are strongly dependant on the major-element composition of phlogopite, $f\left(\mathrm{O}_{2}\right), P\left(\mathrm{H}_{2} \mathrm{O}\right)$ and pressure in the crystallization environment.

Our data indicate that carbonatitic micas can be reliably distinguished from macrocrystic phlogopite in kimberlites on the basis of their trace-element composition. The most profound difference is observed in the abundances of $\mathrm{Cr}, \mathrm{Ni}, \mathrm{Mn}$ and $\mathrm{Nb}$. All kimberlitic samples are characteristically enriched in $\mathrm{Cr}$ and $\mathrm{Ni}$ with respect to the ones from carbonatites, which correlates well with much higher levels of these elements in the kimberlitic magma relative to the average carbonatite (Fig. 2). Higher concentrations of $\mathrm{Mn}, \mathrm{Nb}, \mathrm{Ta}$ and $\mathrm{Sr}$ in carbonatitic phlogopite are also in accord with enrichment of these elements in carbonatites relative to kimberlites (Fig. 2). According to our data, variations in $\mathrm{Ba}, \mathrm{Rb}$ and $\mathrm{V}$ contents are comparable in mica from both rock types, therefore these elements cannot be used as a petrogenetic indicator.

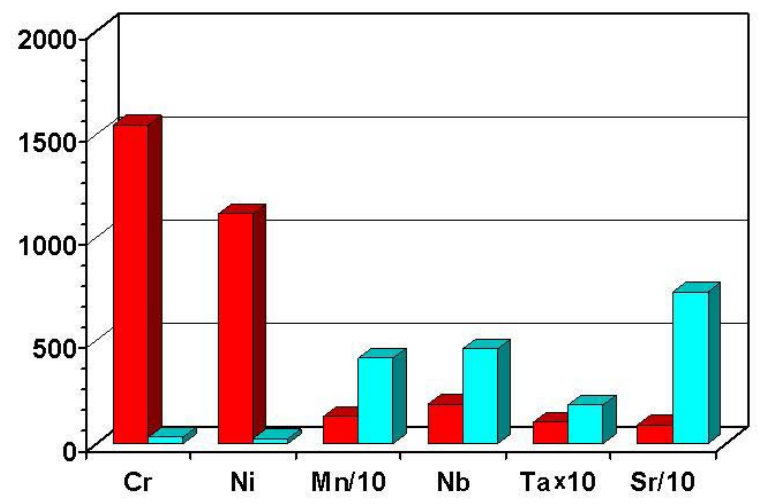

Fig. 2 Abundances of selected trace elements in the average hypabyssal kimberlite (red) and calciocarbonatite (blue) (Chakhmouradian, unpublished data). All values are in parts per million.

\section{References}

Bagdasarov, Yu.A., Vlasova, E.V. and Skosyreva, M.V., 1985. Typomorphism of micas. Bulletin of Academy of Sciences U.S.S.R., Geology Series 6, 78-92.

Birkett, T.C., McCandless, T.E., and Hood, C.T., 2004. Petrology of the Renard igneous bodies: host rock for diamond in the northern Otish Mountains region, Quebec. Lithos 76, 475-490.

Brod, J.A., Gaspar, J.C., de Araújo, D.P., Gibson, S.A., Thompson, R.N. and Junqueira-Brod, T.C., 2001. Phlogopite and tetra-ferriphlogopite from Brazilian carbonatite complexes: petrogenetic constraints and implications for mineral-chemistry systematics. Journal of Asian Earth Sciences 265-296.

Chakhmouradian, A.R., Böhm, C.O., Demény, A., Reguir, E.P., Hegner, E., Halden, N., and Yang, P. 2009. "Kimberlite" from Wekusko Lake, Manitoba: a diamond-indicator-bearing beforsite and not a kimberlite, after all. Extended Abstracts $C D, 9^{\text {th }}$ International Kimberlite Conference, Frankfurt, Abstract No. 9IKC-A-00083.pdf.

Foley, S.F., Jackson, S.E., Fryer, B.J., Greenough, J.D. and Jenner, G.A., 1996. Trace element partition coefficients for clinopyroxene and phlogopite in an alkaline lamprophyre from Newfoundland by LAMICP-MS. Geochimica et Cosmochimica Acta 60(4), 629-638.

Gaspar, J.C. and Wyllie, P.J., 1987. The phlogopites from the Jacupiranga carbonatite intrusions. Mineralogy and Petrology 36, 121-134.

Grégoire, M., Bell, D.R. and Le Roex, A.P., 2003. Garnet lherzolites from the Kaapvaal craton (South Afrika): trace-element evidence for a metasomatic history. Journal of Petrology 44(4), 629-657.

Lee, M.J., Garcia, D., Moutte, J. and Lee, J.I., 2003. Phlogopite and tetraferriphlogopite from phoscorite and carbonatite associations in the Sokli massif, Northern Finland. Geoscience Journal 7(1), 9-20.

Mitchell, R.H., 1995. Kimberlites, Orangeites and Related Rocks. Plenum Press, New York.

Schmidt, K.H., Botazzi, P., Vannucci, R. and Mengel, K., 1999. Trace element partitioning between phlogopite, clinopyroxene and leucite lamproite melt. Earth and Planetary Science Letters 168, 287-299.

Tischendorf, G., Förster, H.-J., and Gottesmann, B., 2001. Minor- and trace-element composition of trioctahedral micas: a review. Mineralogical Magazine 65(2), 249-276. 